\title{
Genotype by Environment Interaction for Grain Yield and Association among Stability Parameters in Bread Wheat (Triticum aestivum L.)
}

\author{
Alemayehu Balcha \\ South Agricultural Research Institute, Hawassa Agricultural Research Centre, Hawassa, Ethiopia \\ Email: albalcha@yahoo.com
}

How to cite this paper: Balcha, A. (2020) Genotype by Environment Interaction for Grain Yield and Association among Stability Parameters in Bread Wheat (Triticum aestivum L.). American Journal of Plant Sciences, 11, 1-10.

https://doi.org/10.4236/ajps.2020.111001

Received: November 25, 2019

Accepted: December 28, 2019

Published: December 31, 2019

Copyright $\odot 2020$ by author(s) and Scientific Research Publishing Inc. This work is licensed under the Creative Commons Attribution International License (CC BY 4.0).

http://creativecommons.org/licenses/by/4.0/

\begin{abstract}
Bread wheat (Triticum aestivum L.) is most important cereal crop in Ethiopia. Lack of genotypes with wide stability across environments has been one of the most important constraints of wheat production in the country. Field experiments were conducted in Halaba and Bule, South Ethiopia, in 2016 and 2017, in order to estimate grain yield stability and association among stability parameters. Fifteen improved bread wheat genotypes were grown under randomized complete block design with three replications. Mean yield for Halaba 2016, Halaba 2017, Bule 2016 and Bule 2017 was 3.83, 1.89, 2.90 and 3.59 tons/ha, respectively. Genotypes Lemu (3.25 tons/ha) and Mandoyu (3.18 tons/ha) had high mean yield, and low values of environmental variance $\left(\mathrm{S}^{2} \mathrm{i}\right)$, coefficient of variation $(\mathrm{CVi})$, stability variance $\left(\delta^{2} \mathrm{i}\right)$, ecovalence $(\mathrm{Wi})$ and deviation from regression ( $\mathrm{S}^{2} \mathrm{di}$ ). Genotypes Biqa (3.69 tons/ha) and Shorima (3.66 tons/ha) had high mean yield, coefficient of regression (bi) and coefficient of determination $\left(R^{2} \mathrm{i} \geq 0.94\right)$ as well as low values of $\delta^{2} \mathrm{i}$, Wi and $S^{2} \mathrm{di}$. Grain yield had positive rank correlation with bi $(\mathrm{r}=0.75, \mathrm{p}<0.01), \mathrm{R}^{2} \mathrm{i}(\mathrm{r}=$ $0.70, \mathrm{p}<0.01)$ and rank sum $(\mathrm{r}=0.82, \mathrm{p}<0.01)$. Rank correlation among $\delta^{2} \mathrm{i}$, $\mathrm{Wi}$ and $\mathrm{S}^{2}$ di was high $(\mathrm{r} \geq 0.98, \mathrm{p}<0.01)$. Present study showed that genotypes Lemu, Mandoyu and Hidase, and Biqa and Shorima would be recommended for wide adaption, and for more favorable environments, respectively. It could also be suggested that one of $\mathrm{Wi}, \delta^{2} \mathrm{i}, \mathrm{S}^{2} \mathrm{di}$ and rank sum would be used for ranking of genotypes.
\end{abstract}

\section{Keywords}

Grain Yield, Stability, Rank Correlations, Bread Wheat, Triticum aestivum 


\section{Introduction}

Bread wheat (Triticum aestivum L.) is the most important cereal crop in Ethiopia occupying over 1.70 million ha of land (16.63\% of the area allocated to cereals) and producing over 4.54 million tons of grain (17.88\% of cereals production) per year [1]. In Southern Ethiopia, it occupies over 127,212 ha $(14.37 \%$ of the area allocated to cereals) producing over 0.33 million tons of grain $(15.42 \%$ of cereals production). The national as well as regional yield of wheat, 2.67 and 2.59 tons/ha, respectively, is low which could be partly attributed to the use of varieties less adapted to the changing environments.

Quantitative traits such as grain yield are usually influenced by genotype, environment and genotype by environment interaction. However, the presence of genotype by environment interaction has been shown to reduce progress in selection of superior and stable genotypes by masking genotypic effects [2] [3] [4]. The differential response of genotypes across environments could be due to differences in expression of different sets or the same set of genes in different environments [5]. Thus, the presence of predictable as well as unpredictable environmental variations requires selection of stable genotypes which react less with the changes in environments [2].

Yield stability usually refers to a genotype's ability to perform consistently at high or low yield levels, across a wide range of environments [6]. Several methods have been proposed to estimate the relative stability of performance of genotypes across environments. These include deviation from regression [2], environmental variance [7], coefficient of variation [8], stability variance [9], ecovalence [10] and coefficient of determination [11]. The linear regression of genotype mean yield on the average of all genotypes in each environment gives regression coefficient and deviation from regression. Thus, an ideal genotype has above average yield, regression coefficient equal to unity and near-zero deviation from regression [2]. On the other hand, stability variance [9] and ecovalence [10] have been used to estimate the contribution of each genotype to the genotype by environment sum of squares where genotypes with the lowest values are considered to be most stable.

Using more than one stability estimation method helps to obtain most reliable stability parameter(s) because a single method may not adequately explain performance across different environments [7]. The present study therefore was conducted in order to estimate grain yield stability of improved bread wheat genotypes and the association among stability parameters.

\section{Materials and Methods}

Field experiments were conducted at experiment stations of Hawassa Agricultural Research Centre, Hawassa, Ethiopia, in Halaba and Bule, during 2016 and 2017 cropping seasons so that the location-year combinations gave four environments, namely, Halaba 2016, Halaba 2017, Bule 2016 and Bule 2017. Halaba is located at $07^{\circ} 18^{\prime} 45^{\prime \prime} \mathrm{N}, 37^{\circ} 06^{\prime} 49^{\prime \prime} \mathrm{E}$ and $1765 \mathrm{~m}$ above sea level. It has annual 
average rainfall and temperature of about $857 \mathrm{~mm}$ and $22.22^{\circ} \mathrm{C}$, respectively, whereas rainfall during experiment period (July to October) was 394 and 236 $\mathrm{mm}$ in 2016 and 2017, respectively. Bule is located at $06^{\circ} 17^{\prime} 99^{\prime \prime} \mathrm{N}, 38^{\circ} 24^{\prime} 33^{\prime \prime} \mathrm{E}$ and $2822 \mathrm{~m}$ above sea level. It has annual average rainfall and temperature of about $1520 \mathrm{~mm}$ and $16.25^{\circ} \mathrm{C}$, respectively, whereas rainfall during experiment period (July to December) was 703 and $939 \mathrm{~mm}$ in 2016 and 2017, respectively. The respective soils of Halaba and Bule were loam and clay loam, respectively.

Fifteen improved bread wheat genotypes including Wane, Lemu, Kingbird, Liben, Bulluq, Obora, Dambal, Honqolo, Biqa, Sanate, Mandoyu, Hidase, Ogolcho, Hulluka and Shorima, obtained from Kulumsa Agricultural Research Centre, Kulumsa, Ethiopia, were grown in randomized complete block design with three replications. Each plot consisted of six rows of $2.5 \mathrm{~m}$ long with $20 \mathrm{~cm}$ between rows, and $1 \mathrm{~m}$ between replications. The seed was drilled using $150 \mathrm{~kg} / \mathrm{ha}$ seeding rate. Plots received $65 \mathrm{~kg} / \mathrm{ha} \mathrm{N}$ in the form of NPS and urea, and 38 $\mathrm{kg} / \mathrm{ha} \mathrm{P}_{2} \mathrm{O}_{5}$ in the form of NPS applied at planting time. Weeds were controlled with hand weeding throughout the experiment period. Grain yield (tons/ha) was recorded using the four central rows per plot and estimated after adjusting the plot yield to $12.5 \%$ seed moisture content.

Stability parameters were estimated with $\mathrm{Xij}$ is yield of ith genotype in the jth environment, $\mathrm{n}$ is number of genotypes, $\mathrm{m}$ is number of environments, $\mathrm{Xi}$. is mean yield of ith genotype across environments, $X . j$ is mean yield of jth environment and $\mathrm{X}$.. is grand mean.

Environmental variance $\left(\mathrm{S}^{2} \mathrm{i}\right)[7]$ :

$$
\mathrm{S}^{2} \mathrm{i}=\frac{\sum(\mathrm{Xij}-\mathrm{Xi} .)^{2}}{\mathrm{~m}-1}
$$

Coefficient of variation (CVi) [8]:

$$
\mathrm{CVi}=\frac{\mathrm{Si}}{\mathrm{Xi} .} \times 100
$$

Stability variance $\left(\delta^{2} \mathrm{i}\right)[9]$ :

$$
\begin{aligned}
\delta^{2} \mathrm{i}= & \frac{1}{(\mathrm{n}-1)(\mathrm{n}-2)(\mathrm{m}-1)}\left[\mathrm{n}(\mathrm{n}-1) \sum(\mathrm{Xij}-\mathrm{Xi} .-\mathrm{X} . \mathrm{j}+\mathrm{X} . .)^{2}\right. \\
& \left.-\sum \mathrm{i} \sum \mathrm{j}(\mathrm{Xij}-\mathrm{Xi.}-\mathrm{X} . \mathrm{j}+\mathrm{X} . .)^{2}\right]
\end{aligned}
$$

Ecovalence (Wi) [10]:

$$
W i=\sum(X i j-X i .-X . j+X . .)^{2}
$$

Coefficient of regression (bi) was obtained by regressing the yield of each genotype in each environment on environmental index based on the model [2]:

$$
\mathrm{Xij}=\mu \mathrm{i}+\beta \mathrm{ilj}+\delta \mathrm{ij}
$$

where $\mathrm{Xij}$ is yield of ith genotype in jth environment, $\mu \mathrm{i}$ is mean of ith genotype across environments; $\beta i$ is regression coefficient of ith genotype; $I j$ is environmental index (X.j - X..), and $\delta \mathrm{ij}$ is deviation from regression of ith genotype at jth environment. The significance of the regression coefficients was determined 
using the t-test.

Coefficient of determination $\left(\mathrm{R}^{2} \mathrm{i}\right)[11]$ :

$$
\mathrm{R}^{2} \mathrm{i}=\frac{\mathrm{b}^{2} \mathrm{i} \mathrm{S}^{2} \mathrm{IJ}}{\mathrm{S}^{2} \mathrm{i}}
$$

where

$$
\mathrm{S}^{2} \mathrm{IJ}=\frac{\sum \mathrm{I}^{2} \mathrm{j}}{\mathrm{m}-1}
$$

Combined analysis of variance was done by considering environments and replications as random effects and genotypes as fixed effects. The analysis of variance and stability analysis were done using SAS software version 9.0 [12].

\section{Results}

Analysis of variance showed highly significant $(\mathrm{p}<0.01)$ effects of genotype, environment, and genotype $\mathrm{x}$ environment interaction and their respective contribution to the total sum of squares was $40.16 \%, 16.12 \%$ and $25.52 \%$. The Eberhart and Russell's linear regression also showed non-significant $\mathrm{G} \times \mathrm{E}$ (linear) and highly significant pooled deviations (non-linear) components of the regression (Table 1).

Mean grain yields of fifteen genotypes in four environments were depicted in Table 2. Grain yield (tons/ha) ranged from 3.22 (Wane) to 4.89 (Ogolcho) in Halaba 2016; 1.49 (Liben) to 2.57 (Ogolcho) in Halaba 2017; 0.79 (Hulluka) to 4.92 (Sanate) in Bule 2016 and 1.82 (Hulluka) to 4.72 (Shorima) in Bule 2017. Mean grain yield of Halaba 2016, Halaba 2017, Bule 2016, and Bule 2017 was $3.83,1.89,2.90$ and 3.59 tons/ha, respectively.

Mean grain yield $(\mathrm{GY})$, environmental variance $\left(\mathrm{S}^{2} \mathrm{i}\right)$, coefficient of variation $(\mathrm{CVi})$, stability variance $\left(\delta_{\mathrm{i}}^{2}\right)$, ecovalence $(\mathrm{Wi})$, regression coefficient $(\mathrm{bi})$, deviation from regression $\left(S^{2} \mathrm{di}\right)$, coefficient of determination $\left(\mathrm{R}^{2} \mathrm{i}\right)$ and rank sum for fifteen genotypes were presented in Table 3. Mean grain yield (tons/ha) ranged from 1.93 (Hulluka) to 3.69 (Biqa), S'i 0.51 (Mandoyu) to 1.97 (Sanate), CVi 22.55 (Mandoyu) to 58.79 (Hulluka), $\delta^{2} \mathrm{i} 0.07$ (Lemu and Biqa) to 1.59 (Ogolcho), Wi 0.27 (Lemu) to 4.24 (Ogolcho), and bi from 0.73 (Mandoyu) to 1.41 (Shorima). There was also considerable variation in $\mathrm{S}^{2} \mathrm{di}, \mathrm{R}^{2} \mathrm{i}$ and rank sum among genotypes.

The values of rank correlations among grain yield and eight stability parameters were presented in Table 4. Grain yield was positively correlated with bi $(\mathrm{r}=$ $0.75, \mathrm{p}<0.01), \mathrm{S}^{2} \mathrm{di}(\mathrm{r}=0.54, \mathrm{p}<0.05), \mathrm{R}^{2} \mathrm{i}(\mathrm{r}=0.70, \mathrm{p}<0.01)$ and rank sum $(\mathrm{r}=$ $0.82, \mathrm{p}<0.01)$. Similarly, $S^{2} \mathrm{i}$ had positive correlation with $\mathrm{CVi}$, $\delta^{2} \mathrm{i}$, Wi and $S^{2} \mathrm{di}$, and the correlation among $\delta^{2} \mathrm{i}$, Wi and $\mathrm{S}^{2}$ di was high $(\mathrm{r} \geq 0.98, \mathrm{p}<0.01)$.

\section{Discussion}

The contribution of environment (40.16\%) to the total sum of squares was more than that of genotype (16.12\%) and genotype $\times$ environment interaction (25.52\%) indicating substantial variations in growing environments which could 
have been partly attributed to the considerable variations in rainfall among environments, and heavy yellow rust [Puccinia striiformis f. sp.tritici (Pst)] severity in Bule (data not shown). The fluctuations in the growing environments of wheat [13] and linseed [14] in Ethiopia have also been reported. Similarly, low yield of Halaba 2017 could be partly attributed to its low rainfall $(236 \mathrm{~mm}$, 40.10\% lower than that of Halaba 2016) during 2017 cropping season in Halaba.

Table 1. Analysis of variance and Eberhart and Russell's linear regression of grain yield for fifteen bread wheat genotypes grown in four environments.

\begin{tabular}{lcccc}
\hline Sources of variation & DF & SS & MS & $\%$ SS \\
\hline Replication/E & 8 & 18.48 & $2.31^{\star *}$ & 7.09 \\
Environment (E) & 3 & 101.79 & $33.93^{\star *}$ & 40.16 \\
Genotype (G) & 14 & 40.85 & $2.92^{\star *}$ & 16.12 \\
G $\times$ E & 42 & 64.67 & $1.54^{* \star}$ & 25.52 \\
$\quad 14$ & 1.31 & $0.09 \mathrm{~ns}$ & \\
$\quad$ G $\times$ E (linear) & 30 & 20.27 & $0.68^{\star *}$ & \\
Error & 112 & 27.66 & 0.25 & 10.91 \\
Average error & & & 0.083 & \\
CV (\%) & & & 16.28 & \\
\hline
\end{tabular}

** $=$ significant at $\mathrm{p}<0.01, \mathrm{~ns}=$ not significant.

Table 2. Mean grain yield (tons/ha) of fifteen bread wheat genotypes grown in four environments.

\begin{tabular}{ccccc}
\hline Genotypes & Halaba 2016 & Halaba 2017 & Bule 2016 & Bule 2017 \\
\hline Wane & 3.22 & 1.80 & 3.47 & 4.49 \\
Lemu & 3.73 & 2.02 & 3.52 & 3.74 \\
Kingbird & 3.94 & 1.89 & 1.05 & 2.18 \\
Liben & 3.37 & 1.49 & 3.38 & 3.99 \\
Bulluq & 4.01 & 1.99 & 2.75 & 2.60 \\
Obora & 3.84 & 1.68 & 3.55 & 3.09 \\
Dambal & 3.62 & 1.77 & 3.18 & 4.55 \\
Honqolo & 3.42 & 1.86 & 1.49 & 3.70 \\
Biqa & 4.77 & 2.29 & 3.25 & 4.45 \\
Sanate & 3.52 & 1.71 & 4.92 & 4.36 \\
Mandoyu & 3.36 & 2.16 & 3.37 & 3.84 \\
Hidase & 3.84 & 1.63 & 3.59 & 3.75 \\
Ogolcho & 4.89 & 2.57 & 1.59 & 2.58 \\
Hulluka & 3.50 & 1.62 & 0.79 & 1.82 \\
Shorima & 4.40 & 1.89 & 3.62 & 4.72 \\
Mean & 3.83 & 1.89 & 2.90 & 3.59 \\
LSD 0.05 & 0.87 & 0.48 & 0.77 & 1.10 \\
F-ratio (genotype) & $* *$ & $* *$ & $* *$ & $* *$ \\
CV (\%) & 13.38 & 15.27 & 15.84 & 18.28 \\
\hline
\end{tabular}

${ }^{*}=$ significant at $\mathrm{p}<0.01$. 
Table 3. Mean grain yield (tons/ha) and values of eight stability parameters for fifteen bread wheat genotypes grown in four environments.

\begin{tabular}{cccccccccc}
\hline Genotypes & $\mathrm{GY}$ & $\mathrm{S}^{2} \mathrm{i}$ & $\mathrm{CVi}$ & $\delta^{2} \mathrm{i}$ & $\mathrm{Wi}$ & $\mathrm{bi}$ & $\mathrm{S}^{2} \mathrm{di}$ & $\mathrm{R}^{2} \mathrm{i}$ & Rank sum \\
\hline Wane & 3.25 & 1.23 & 34.17 & $0.48^{* *}$ & $1.36^{* *}$ & 1.01 & $0.68^{* *}$ & 0.63 & 15 \\
Lemu & 3.25 & 0.69 & 25.45 & $0.07 \mathrm{~ns}$ & $0.27 \mathrm{~ns}$ & 0.89 & $0.12 \mathrm{~ns}$ & 0.88 & 7 \\
Kingbird & 2.27 & 1.48 & 53.65 & $1.09^{* *}$ & $2.95^{* *}$ & 0.83 & $1.44^{* *}$ & 0.35 & 27 \\
Liben & 3.06 & 1.18 & 35.47 & $0.25^{*}$ & $0.76^{*}$ & 1.11 & $0.37^{*}$ & 0.79 & 16 \\
Bulluq & 2.84 & 0.72 & 29.88 & $0.29^{*}$ & $0.86^{*}$ & 0.79 & $0.38^{*}$ & 0.65 & 20 \\
Obora & 3.04 & 0.92 & 31.51 & $0.24^{*}$ & $0.72^{*}$ & 0.95 & $0.35^{*}$ & 0.74 & 16 \\
Dambal & 3.28 & 1.34 & 35.29 & $0.29^{*}$ & $0.85^{*}$ & 1.20 & $0.38^{*}$ & 0.81 & 13 \\
Honqolo & 2.62 & 1.22 & 42.20 & $0.50^{* *}$ & $1.41^{* *}$ & 1.00 & $0.71^{* *}$ & 0.61 & 24 \\
Biqa & 3.69 & 1.30 & 30.89 & $0.07 \mathrm{~ns}$ & $0.28 \mathrm{~ns}$ & $1.30^{*}$ & $0.04 \mathrm{~ns}$ & 0.98 & 3 \\
Sanate & 3.63 & 1.97 & 38.64 & $1.30^{* *}$ & $3.47^{* *}$ & 1.03 & $1.74^{* *}$ & 0.41 & 17 \\
Mandoyu & 3.18 & 0.51 & 22.55 & $0.16 \mathrm{~ns}$ & $0.51 \mathrm{~ns}$ & 0.73 & $0.17 \mathrm{~ns}$ & 0.78 & 12 \\
Hidase & 3.21 & 1.11 & 32.89 & $0.14 \mathrm{~ns}$ & $0.48 \mathrm{~ns}$ & 1.13 & $0.22 \mathrm{~ns}$ & 0.87 & 10 \\
Ogolcho & 2.91 & 1.96 & 48.18 & $1.59^{* *}$ & $4.24^{* *}$ & 0.86 & $2.10^{* *}$ & 0.29 & 26 \\
Hulluka & 1.93 & 1.29 & 58.79 & $1.02^{* *}$ & $2.75^{* *}$ & 0.75 & $1.30^{* *}$ & 0.33 & 27 \\
Shorima & 3.66 & 1.60 & 34.60 & $0.21 \mathrm{~ns}$ & $0.66^{*}$ & $1.41^{*}$ & $0.13 \mathrm{~ns}$ & 0.94 & 7 \\
Mean & 3.05 & & & & & & & & \\
\hline
\end{tabular}

${ }^{*}{ }^{* *}=$ significant at $\mathrm{p}<0.05$ and $\mathrm{p}<0.01$, respectively; $\mathrm{ns}=$ non-significant.

Table 4. Rank correlation among grain yield and eight stability parameters of fifteen bread wheat genotypes grown in four environments.

\begin{tabular}{ccccccccc}
\hline Parameters & $\mathrm{S}^{2} \mathrm{i}$ & $\mathrm{CVi}$ & $\delta^{2} \mathrm{i}$ & $\mathrm{W}^{2} \mathrm{i}$ & $\mathrm{bi}$ & $\mathrm{S}^{2} \mathrm{di}$ & $\mathrm{R}^{2} \mathrm{i}$ & Rank sum \\
\hline $\mathrm{GY}$ & $-0.22 \mathrm{~ns}$ & $0.44 \mathrm{~ns}$ & $0.46 \mathrm{~ns}$ & $0.49 \mathrm{~ns}$ & $0.75^{* *}$ & $0.54^{*}$ & $0.70^{* *}$ & $0.82^{* *}$ \\
$\mathrm{~S}^{2} \mathrm{i}$ & & $0.70^{* *}$ & $0.63^{*}$ & $0.60^{*}$ & $-0.39 \mathrm{~ns}$ & $0.51^{*}$ & $0.31 \mathrm{~ns}$ & $0.27 \mathrm{~ns}$ \\
$\mathrm{CV}$ & & & $0.82^{* *}$ & $0.80^{* *}$ & $0.03 \mathrm{~ns}$ & $0.78^{* *}$ & $0.68^{* *}$ & $0.74^{* *}$ \\
$\delta^{2} \mathrm{i}$ & & & & $1.00^{* *}$ & $0.29 \mathrm{~ns}$ & $0.98^{* *}$ & $0.90^{* *}$ & $0.86^{* *}$ \\
$\mathrm{~W}^{2} \mathrm{i}$ & & & & $0.33 \mathrm{~ns}$ & $0.98^{* *}$ & $0.92^{* *}$ & $0.88^{* *}$ \\
$\mathrm{bi}$ & & & & & $0.38 \mathrm{~ns}$ & $0.63^{*}$ & $0.59^{\star}$ \\
$\mathrm{S}^{2} \mathrm{di}$ & & & & & & $0.94^{* *}$ & $0.89^{* *}$ \\
$\mathrm{R}^{2} \mathrm{i}$ & & & & & & & & $0.94^{* *}$
\end{tabular}

${ }^{*}, * *$ significant at $\mathrm{p}<0.05$ and $\mathrm{p}<0.01$, respectively; $\mathrm{ns}=$ non-significant.

Genotype $\times$ environment interaction was partitioned into linear and non-linear components because the variations in both the regression coefficients and deviations from regressions are of paramount importance to explain total variation in grain yield [2]. The lack of significant contribution of $\mathrm{G} \times \mathrm{E}$ (linear) relative to pooled deviations to the total sum of squares would suggest that the variation in regression slopes may not be an appropriate measure of adaptability as it was reported in other studies [9] [15] [16] [17]. Linear regression method may be most effective to measure adaptability by using single environmental 
factor as it was used by Finlay and Wilkinson [15].

The values of deviations from regressions indicate suitability of linear regression coefficients to estimate performance of genotypes across environments. If deviation from regression is significantly different from zero, the performance of a genotype cannot be predicted by using regression value [2] [15]. Thus, genotypes Wane, Kingbird, Honqolo, Sanate, Ogolcho and Hullaka had high deviation from regression $\left(\mathrm{S}^{2} \mathrm{di} \geq 0.68, \mathrm{p}<0.01\right)$ and their performance can hardly be predicted with linear regression.

The performance of a genotype in an environment depends on a mean performance, a linear response to the environment and deviation from regression [16]. Thus, regression coefficient (bi) values less than 1.0 and more than 1.0 indicate adaptability to unfavorable and favorable environments, respectively, whereas bi $=1.0$ indicates average adaptability [18]. However, an ideal genotype has high mean yield, a regression coefficient equal to unity $(\mathrm{bi}=1.0)$ and the deviations from regression as small as possible $\left(S^{2} \mathrm{di}=0\right)$ [2]. Accordingly, genotypes Lemu, Mandoyu and Hidase were most stable and this was confirmed by high coefficient of determination $\left(\mathrm{R}^{2} \mathrm{i} \geq 0.78\right)$ [11]. When $b i=1.0$ is associated with low mean yield, genotypes are poorly adapted to all environments. Thus, genotypes Kingbird, Ogolcho and Hulluka having low mean yield (1.93 - 2.91 tons/ha) and $\mathrm{R}^{2} \mathrm{i}\left(\mathrm{R}^{2} \mathrm{i}=0.29-0.35\right)$, and high $\mathrm{S}^{2}$ di were poorly adapted to all environments. On the other hand, Biqa $(\mathrm{bi}=1.30)$ and Shorima $(\mathrm{bi}=1.41)$ having high mean yield (3.69 and 33.66 tons/ha, respectively), above average bi values, low $S^{2}$ di values, and high coefficients of determination $\left(R^{2} i \geq 0.94\right)$ were considered to be most adapted to favorable environments.

The non-significant correlation between bi and $S^{2} i(r=-0.39)$ was in contrary to the fact that differences in $\mathrm{S}^{2} \mathrm{i}$ mainly depend on differences in bi [6] [16] [17]. Thus, the weak correlation between $\mathrm{S}^{2} \mathrm{i}$ and bi could be attributed to low variation in regression coefficients [17]. Coefficient of determination $\left(\mathrm{R}^{2} \mathrm{i}\right)$ indicates the variations in grain yield that could be attributed to linear regression on the environmental means. High correlation between bi and $\mathrm{R}^{2} \mathrm{i}$ is expected because $\mathrm{R}^{2} \mathrm{i}$ is directly proportional to the square of the regression coefficient as $\mathrm{R}^{2} \mathrm{i}=$ $\mathrm{b}^{2} \mathrm{iS}^{2} \mathrm{Ij} / \mathrm{S}^{2} \mathrm{i}$ [11]. Thus, like large $\mathrm{S}^{2} \mathrm{di}$, low $\mathrm{R}^{2} \mathrm{i}$ indicates inadequacy of using regression model to estimate the stability of genotypes as it was observed for Kingbird, Sanate, Ogolcho and Hulluka having very low $\mathrm{R}^{2} \mathrm{i}$ values $(0.29-0.41)$. Moreover, moderate correlation $(\mathrm{r}=0.63, \mathrm{p}<0.05)$ between bi and $\mathrm{R}^{2} \mathrm{i}$ could have been attributed to limited variation in bi as it was reported by Vasilj and Minas [19].

The mathematical relationship between $S^{2} \mathrm{di}$ and bi $\left(\mathrm{S}^{2} \mathrm{di}=(\mathrm{m}-1)\right.$ $\left(\mathrm{S}^{2} \mathrm{i}-\mathrm{b}^{2} \mathrm{i} \mathrm{S}^{2} \mathrm{Ij}\right) /(\mathrm{m}-2)$ shows that $\mathrm{S}^{2}$ di has a low sensitivity to the variation in bi because $S^{2}$ di is directly proportional to the differences between variance $\left(S^{2} \mathrm{i}\right)$ and square of regression coefficient (bi) [20]. Thus, the low correlation between them $(r=0.38)$ would suggest that both bi and $S^{2}$ di could be jointly used in stability studies. However, linear regression coefficient (bi) is a measure of response of a particular genotype to environmental changes and deviation from regres- 
sion ( $\left.\mathrm{S}^{2} \mathrm{di}\right)$ is a measure of stability [2] [17] [21].

Genotypes Lemu, Biqa, Mandoyu and Hidase had low values of Wi and $\delta^{2} \mathrm{i}$, i.e., small contribution to $\mathrm{GxE}$ interaction, and therefore were considered most stable. The perfect correlation $(\mathrm{r}=1.00, \mathrm{p}<0.01)$ between $\delta^{2} \mathrm{i}$ and $\mathrm{Wi}$ is expected because of their structural similarity, i.e., $\delta^{2} \mathrm{i}$ is a linear combination of $\mathrm{Wi}$ as $\delta^{2} \mathrm{i}=[1 /(\mathrm{m}-1)(\mathrm{n}-2)]\left[\mathrm{n}(\mathrm{n}-1)(\mathrm{Wi})-\sum \mathrm{iWi}\right]$ [22]. This would suggest that using either $\delta^{2} \mathrm{i}$ or Wi could be sufficient to partition $\mathrm{G} \times \mathrm{E}$ interaction variance as it was reported in other studies [3] [7] [17] [18] [22].

The $S^{2}$ di showed highly significant correlation $(\mathrm{r}=0.98, \mathrm{p}<0.01)$ with $\delta^{2} \mathrm{i}$ and Wi suggesting that they were similar in ranking of genotypes. It has also been reported that the heterogeneity in regression lines and the linear fit of regression model reduce the correlation between $\delta^{2} \mathrm{i}$ and $\mathrm{S}^{2} \mathrm{di}$ [3]. Moreover, $\delta^{2} \mathrm{i}$ and Wi assign variance components to each genotype and are more useful in determining the stability of genotypes than those which do not assign a variance component to individual genotype [18] [22].

The high correlation between $\mathrm{Wi}$ and $\mathrm{S}^{2} \mathrm{di}$ is expected because $\mathrm{Wi}$ a function of linear regression coefficient and deviation mean square where its magnitude largely depends on the magnitude of the later because the linear component is usually small [6]. The correlation of $S^{2}$ di with $\mathrm{Wi}$ and $\mathrm{S}^{2} \mathrm{i}$ on the other hand indicates that $S^{2}$ di can be used not only to evaluate the predictability of the estimated response obtained from linear regression, but also to evaluate the relative contribution of a genotype to the $\mathrm{G} \times \mathrm{E}$ interaction, and indirectly its biological stability [20]. Moreover, the moderate correlation $(\mathrm{r}=0.51, \mathrm{p}<0.05)$ between $S^{2}$ di and $S^{2} i$ would indicate the presence of overlap in their estimation of stability. The significant correlation $(r=0.60, p<0.05)$ between $\mathrm{Wi}$ and $\mathrm{S}^{2} \mathrm{i}$ would also show that a substantial proportion of instability (measured by $\mathrm{S}^{2} \mathrm{i}$ ) results from the $\mathrm{G} \times \mathrm{E}$ sum of squares as it was reported by Duarte and Zimmermann [20].

Genotypes exhibiting high yield, and low environmental variance $\left(S^{2} \mathrm{i}\right)$ and coefficient of variation (CVi) are considered more desirable [7] [8]. On the other hand, lack of correlation of grain yield with $\mathrm{S}^{2} \mathrm{i}, \mathrm{CVi}, \delta^{2} \mathrm{i}$ and Wi could suggest the possibility of simultaneous selection of high yield and stable genotypes. However, CVi is not very suitable as a measure of stability because it has the limitation of high yield, high CVi and low yield, low CVi (8).

The positive correlation $(\mathrm{r}=0.75, \mathrm{p}<0.01)$ between grain yield and bi would show that selection for high yield will also increase the response to improvement in environment. However, selection for responsive and high yielding genotype will be difficult because in a series of trials, most environments have about average yield levels and most genotypes have values of bi close to one [17].

Combining yield and stability in the breeding programs will make selection process more successful. Rank sum was produced by assigning a rank of 1 for the highest yield and rank of 1 for the lowest stability variance $\left(\delta^{2} \mathrm{i}\right)$ [4]. Genotypes Lemu, Biqa and Shorima were the most desirable due to their lowest rank sum. The substantial correlation between rank sum and other stability parameters $\left(\delta^{2} \mathrm{i}, \mathrm{Wi}, \mathrm{S}^{2} \mathrm{di}\right.$, and $\mathrm{R}^{2} \mathrm{i}$ ) would also show that rank sum could be used alone or 
jointly with those stability parameters for ranking of genotypes.

A successful variety must produce high yield in favorable environments and still should produce acceptable yield under less favorable ones. Genotypes Lemu, Mandoyu and Hidase, and Biqa and Shorima would be recommended for wide adaption, and for more favorable environments, respectively. It could also be suggested that one of $\mathrm{Wi}, \delta^{2} \mathrm{i}, \mathrm{S}^{2}$ di and rank sum would be used for ranking of genotypes.

\section{Acknowledgements}

The author thanks South Agricultural Research Institute, Hawassa, Ethiopia, for financial support, and Mr. Wondimagegn Amenu for technical assistance throughout the study period.

\section{Conflicts of Interest}

The author declares no conflicts of interest regarding the publication of this paper.

\section{References}

[1] CSA (2017) Agricultural Sample Survey: Report on Area and Production of Major Crops (Private Peasant Holdings, Meher Season), 2016/2017 (2009 E.C.). Volume I, Statistical Bulletin 584, Central Statistical Agency (CSA), Addis Ababa.

[2] Eberhart, S.A. and Russell, W.A. (1966) Stability Parameters for Comparing Varieties. Crop Science, 6, 36-40. https://doi.org/10.2135/cropsci1966.0011183X000600010011x

[3] Pham, H.N. and Kang, M.S. (1988) Interrelationships among and Repeatability of Several Stability Statistics Estimated from International Maize Trials. Crop Science, 28, 925-928. https://doi.org/10.2135/cropsci1988.0011183X002800060010x

[4] Kang, M.S. and Pham, H.N. (1991) Simultaneous Selection for High Yielding and Stable Crop Genotypes. Agronomy Journal, 83, 161-165.

https://doi.org/10.2134/agronj1991.00021962008300010037x

[5] Yang, R.C. and Baker, R.J. (1991) Genotype-Environment Interactions in Two Wheat Crosses. Crop Science, 31, 83-87. https://doi.org/10.2135/cropsci1991.0011183X003100010021x

[6] Becker, H.C. (1981) Correlations among some Statistical Measures of Phenotypic Stability. Euphytica, 30, 835-840. https://doi.org/10.1007/BF00038812

[7] Lin, C.S., Binns, M.R. and Lefkovitch, L.P. (1986) Stability Analysis: Where Do We Stand? Crop Science, 26, 894-900. https://doi.org/10.2135/cropsci1986.0011183X002600050012x

[8] Francis, T.R. and Kannenberg, L.W. (1978) Yield Stability Studies in Short-Season Maize. 1. A Descriptive Method for Grouping Genotypes. Canadian Journal of Plant Science, 58, 1029-1034. https://doi.org/10.4141/cjps78-157

[9] Shukla, G.K. (1972) Some Statistical Aspects of Partitioning Genotype-Environmental Components of Variability. Heredity, 29, 237-245. https://doi.org/10.1038/hdy.1972.87

[10] Wricke, G. (1962) Uber eine methode zur erfassung der okologischen streubreite in feldversuchen. $Z$. Pflanzenzuecht, 47, 92-96. 
[11] Pinthus, J.M. (1973) Estimate of Genotypic Value: A Proposed Method. Euphytica, 22, 121-123. https://doi.org/10.1007/BF00021563

[12] SAS Institute (2002) SAS/STAT 9.0 User’s Guide. SAS Inst., Cary.

[13] Tesemma, T., Tsegaye, S., Belay, G., Bechere, E. and Mitiku, D. (1998) Stability of Performance of Tetraploid Wheat Landraces in the Ethiopian Highland. Euphytica, 102, 301-308. https://doi.org/10.1023/A:1018361309207

[14] Adugna, W. and Labuschagne, M.T. (2002) Genotype-Environment Interactions and Phenotypic Stability Analyses of Linseed in Ethiopia. Plant Breeding, 121, 66-71. https://doi.org/10.1046/j.1439-0523.2002.00670.x

[15] Finlay, K.W. and Wilkinson, G.N. (1963) The Analysis of Adaptation in Plant-Breeding Programme. Australian Journal of Agricultural Research, 14, 742-754. https://doi.org/10.1071/AR9630742

[16] Powell, W., Caligari, P.D.S., Phillips, M.S. and Jink, J.L. (1986) The Measurement and Interpretation of Genotype by Environment Interaction in Spring Barley (Hordeum vulgare). Heredity, 56, 255-262. https://doi.org/10.1038/hdy.1986.38

[17] Becker, H.C. and Leon, J. (1988) Stability Analysis in Plant Breeding. Plant Breeding, 101, 1-23. https://doi.org/10.1111/j.1439-0523.1988.tb00261.x

[18] Kang, M.S. and Miller, J.D. (1984) Genotype $\times$ Environment Interactions for Cane and Sugar Yield and Their Implications in Sugarcane Breeding. Crop Science, 24, 435-440. https://doi.org/10.2135/cropsci1984.0011183X002400030002x

[19] Vasilj, D. and Milas, S. (1984) Relationship between Yield Stability Parameters Estimated with Different Methods for Some Maize and Wheat Genotypes. Vortr. Pflanzenziichtg, 7, 266-279.

[20] Duarte, J.B. and Zimmermann, M.J.O. (1995) Correlation among Yield Stability Parameters in Common Bean. Crop Science, 35, 905-912. https://doi.org/10.2135/cropsci1995.0011183X003500030046x

[21] Breese, E.L. (1969) The Measurement and Significance of Genotype-Environment Interaction in Grasses. Heredity, 21, 27-44. https://doi.org/10.1038/hdy.1969.3

[22] Kang, M.S., Miller, J.D. and Darrah, L.L. (1987) A Note on Relationship between Stability Variance and Ecovalence. Journal of Heredity, 78, 107. https://doi.org/10.1093/oxfordjournals.jhered.a110322 